\title{
Quantitative ultrasound and bone health
}

\author{
Karen M Knapp, $\mathrm{PhD}^{(\mathrm{I})}$
}

\section{Knapp KM \\ Quantitative ultrasound and bone health. Salud Publica Mex 2009;5 I suppI I:S I 8-S24.}

\begin{abstract}
This review of quantiative ultrasound (QUS) and bone health uses the current literature to summarise the clinical and research effectiveness of QUS. QUS has been demonstrated to have the ability to predict fracture, particularly at the hip. However, the magnitude of prediction is fracture-site, measurement-site and device dependent. The correlations between dual X-ray absorptiometry (DXA) and bone mineral density (BMD) are weak to moderate, resulting in different subjects being identified as being at risk of fracture by the two different methods. QUS is sensitive to age and menopauserelated changes and to clinical risk factors and lifestyle factors associated with osteoporosis. Whilst a limited ability of QUS to monitor therapeutic intervention has been demonstrated, this is still an area where it's poorer precision, in comparison to DXA, results in limited applicability. Whilst DXA remains the gold standard for the diagnosis of osteoporosis, QUS may be of use for the prediction of those at risk of future fracture in areas where there is limited availability of DXA.
\end{abstract}

Key words: osteoporosis; ultrasound; bone density; fracture

\author{
Knapp KM \\ Ultrasonido cuantitativo y salud ósea. \\ Salud Publica Mex 2009;5I supl I:S18-S24.
}

\section{Resumen}

En esta revisión sobre el Ultrasonido Cuantitativo (QUS) y su aplicación en la evaluación de la salud de los huesos, se analiza detalladamente la literatura disponible para conocer su papel y efectividad en la clínica cotidiana y en los programas de investigación. El QUS ha probado ser útil para predecir fracturas, especialmente de la cadera. Sin embargo, la exactitud de la predicción depende del sitio de fractura que se desea evaluar, del sitio anatómico donde se realiza la medición y de los diferentes instrumentos. La correlación que existe entre densitometría de rayos X (DXA) y QUS puede ser débil a moderada, porque ambos métodos determinan diferentes componentes de la masa ósea relacionados con la presentación de las fracturas. El resultado del QUS como el del DXA también es sensible a la edad, cambios relacionados con la menopausia, a factores de riesgo clínicos y de estilo de vida relacionados con la osteoporosis. Se ha demostrado que el QUS puede servir para monitoreo de las intervenciones terapéuticas, de manera menos sensible que el DXA, lo que limita su aplicación con este propósito. El DXA sigue siendo el estándar diagnóstico de oro para la osteoporosis; la capacidad del QUS para predecir fracturas, lo vuelve una buena alternativa en lugares y/o países donde el acceso a DXA tiene limitaciones.

Palabras clave: osteoporosis; ultrasonido; densidad ósea; fractura
$\mathrm{T}$ he use of quantitative ultrasound (QUS) for the measurement of bone was first reported by Langton et al. in 1984. Since 1984, the use of QUS has expanded vastly, and it has been widely used for research and clinical purposes. ${ }^{1}$ The first ultrasound system repor- ted by Langton used transmission mode ultrasound with a transmitting and a receiving transducer placed either side of the calcaneus, which was placed within a water bath. ${ }^{1}$ The calcaneus was chosen as a site for measurement since it is easily accessible, with the

(I) University of Exeter, United Kingdom.

Received on: January 7, 2008 • Accepted on: March 7, 2008

Address reprint requests to: Dr K M Knapp. University of Exeter, Physics, Stocker Road, Exeter, Devon, EX4 4QL, UK. E-mail:K.M.Knapp@exeter.ac.uk 
medial and lateral aspects being relatively flat and parallel. It contains approximately $90 \%$ trabecular bone, which has a high metabolic turnover rate and a pattern of bone loss similar to the spine. ${ }^{2,3}$ The majority of subsequent ultrasound systems have been based upon this prototype, although dry systems which use ultrasound gel as a coupling medium instead of water have also been introduced. Much of the research done into QUS has therefore been performed using ultrasound measurements of the calcaneus. However, there have also been devices introduced that measure the patella, tibia, phalanges, radius and metatarsal, using a range of techniques including transmission and semi-reflection or axial transmission mode ultrasound. ${ }^{4-10}$

Dual X-ray absorptiometry (DXA) is currently the most widely used tool in the United Kingdom for the measurement of bone mineral density (BMD) and is widely regarded as the gold standard for the diagnosis of osteoporosis and fracture prediction. However, in many areas there are inadequate resources to meet the demand. ${ }^{11}$ Quantitative ultrasound offers a radiationfree, inexpensive, non-invasive alternative to DXA. ${ }^{11,12}$

\section{What QUS measures}

A number of authors have investigated the ability of QUS to measure the density and micro-architectural properties of bone., ${ }^{3,13-18}$ Results from in-vitro studies in bovine bone have found the ultrasound derived modulus of elasticity correlates strongly with values of bone breaking strength derived from static loading. ${ }^{19-21}$ A number of studies have reported QUS parameters to be significantly associated with bone structure independently of BMD. ${ }^{3,16-18,20}$ Whilst Mehta et al. reported ultrasound velocity and elasticity to be strongly connected with material elasticity as measured by mechanical testing. ${ }^{14}$ Broadband ultrasound attenuation (BUA) values have been reported to be dependent upon trabecular orientation in vitro. ${ }^{22,23}$ However, high correlation's in-vivo of $\mathrm{r}=0.75$ to $\mathrm{r}=0.90$ between $\mathrm{BUA}$ and $\mathrm{BMD}$ at the calcaneus using QUS and DXA with matched regions of interest have been reported, ${ }^{24,25}$ suggesting that QUS may reflect micro-architecture, but only to a small extent. Njeh et al. in a comprehensive review of whether QUS is dependent on structure concluded that ultrasound attenuation is due to structural parameters as well as dependent on density. ${ }^{15}$

\section{Precision}

QUS has demonstrated limited use in the monitoring of patients undergoing treatment, primarily due to its poor precision in comparison with DXA, leading to long time intervals being required to detect changes in bone. ${ }^{26-28}$ The precision of QUS is generally reported to be poorer than that of DXA. There are currently QUS devices available for measuring a range of anatomical sites including both predominantly trabecular and predominantly cortical bone sites. The calcaneus is a site with a high trabecular bone content, whilst some other sites of measurement are primarily cortical. When measuring the speed of sound (SOS), the coefficient of variation can appear particularly favourable for cortical sites due to the higher SOS in cortical bone compared to trabecular bone. When the coefficient of variation is calculated for cortical bone, division by a larger denominator is applied than for measurements in trabecular bone, giving the appearance of better precision at the cortical sites. Broadband ultrasound attenuation precision also appears to be poorer than its corresponding SOS precision in the same devices for the identical reason. As such, it is difficult to compare precision results between ultrasound devices and different anatomical regions. In order to make a useful comparison the precision results need to be standardised (standardised precision - SP) to the population standard deviation, signifying the error within the useful clinical range, of the individual device. Frost $e t$ al. found short term precision to range from $0.3-0.4 \%$ (SP 0.16-0.23) in the Hologic Sahara ${ }^{29}$ and 1.21-1.62\% (SP 0.14-0.19) for the Osteometer DTU-1. ${ }^{30}$ Precision results for the Sunlight Omnisense have been reported to range from 0.2 to $1.48 \%$ depending on the anatomical site measured..$^{31-33}$

As a result of the poor precision of QUS in comparison to DXA, optimisation of measurements to reduce precision errors is of utmost importance. Parametric imaging has been introduced on some calcaneal scanners in an attempt to improve precision. ${ }^{30,34}$ In contrast to the fixed transducers of many calcaneal systems, the Sunlight Omnisense uses hand-held probes to enable measurement of multiple peripheral sites (figure 1). ${ }^{33}$ This has the potential to influence the precision results, especially inter-operator precision. Operator training is therefore particularly important on this device to minimise precision errors.

\section{Age-related changes}

QUShas been demonstrated to be sensitive to age-related, pubertal stage and menopause-related changes in bone. $5,27,32,33,35-37$ Multi-site quantitative ultrasound has demonstrated differing peak bone mass for different sites, with the weight bearing sites tending to peak earlier and have a lower rate of bone loss postmenopausally. ${ }^{32,33}$ Studies evaluating premenopausal age related changes 


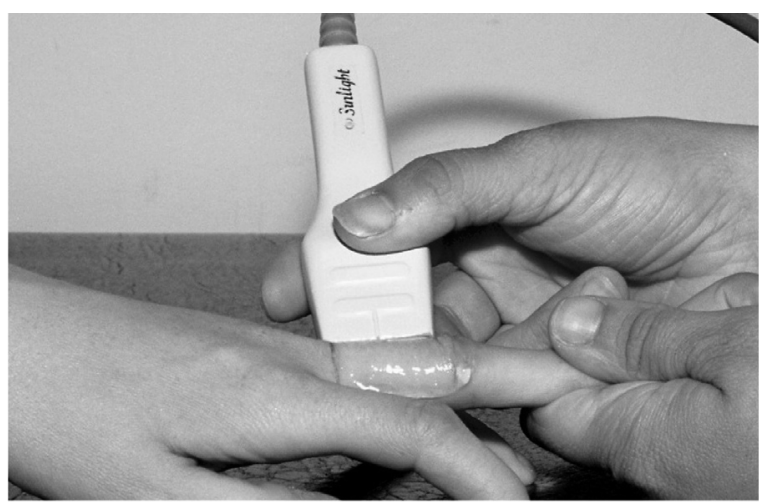

Figure I. Measurement of the thiRd PROXimal PHALANX USING The SUnLIGHT OMNISENSE

at the phalanges using the DBM-sonic have also found age-related bone loss premenopausally. ${ }^{4,5}$

\section{Correlation with DXA}

The correlation of QUS measurements with BMD has generally yielded weak to moderate correlations, particularly when peripheral QUS measurement sites have been correlated with axial BMD. ${ }^{7,33}$ Faulkner et al. found correlations ranging from $0.26-0.63$ for calcaneal QUS and DXA of the spine, hip, forearm and whole body. ${ }^{38}$ He et al found correlations ranging from $0.30-0.41$ for calcaneal QUS parameters and whole body DXA and correlations ranging from $0.28-0.41$ between calcaneal QUS and proximal femur BMD regions of interest (ROI's).$^{39}$ Site matched correlations between BUA, velocity of sound (VOS) and BMD at the calcaneus have given better correlations ranging from $0.66-0.73 .{ }^{20}$ Some of the highest site matched correlations have been reported by Chappard et al. and Laugier et al. Chappard et al. reported high correlations in vivo of $0.78-0.90$ between BUA and BMD at the calcaneus from their study using imaging QUS and DXA where site matched regions of interest were able to be correlated. ${ }^{24}$ In a similar study Laugier et al used imaging QUS and QCT in cadavers to investigate the relationship between site matched measurements of BUA and BMD and reported high correlations of $\mathrm{r}=0.75-0.88 .^{25}$

\section{Fracture discrimination}

Quantitative ultrasound measurements at the calcaneus have been demonstrated to be able to discriminate between cases and controls with vertebral crush fractures and non-spine fractures. ${ }^{1,10,27,39-45}$
Some of the earliest strongest evidence to support the use of QUS for discriminating between osteoporotic fractures and controls has come from large prospective studies. The first of these was published in 1990, when Porter et al. measured 1414 women over the age of 69 who were in residential accommodation. ${ }^{46}$ Measurements were performed at the calcaneus using the original Langton device. The women were followed up over a period of two years during which time a total of 73 women suffered a hip fracture. The fracture group was found to have a lower BUA than the non-fracture group and were also found to be more active and have a lower cognisance score. Table I outlines a number of cross-sectional and prospective studies demonstrating the ability of QUS measurements at various sites to predict osteoporotic fracture. In all these studies, QUS is a good predictor or discriminator of hip or non-spine fractures. ${ }^{9,45,47-53}$ In a meta-analysis of QUS and fractures, Marín et al. reported the strength of association between QUS with non-spinal fractures to be similar to axial or peripheral BMD measurements. However, QUS was shown to be inferior to the association between BMD measured at the hip and hip fracture. ${ }^{54}$ Despite its ability to predict non-spine and hip fractures, the data to support the ability of QUS to predict vertebral fractures is variable. However, calcaneal QUS generally has better prediction and discrimination of vertebral fracture than other sites. ${ }^{27,33,55-64}$

\section{Risk factors and secondary osteoporosis}

Studies have found QUS to be sensitive to clinical risk factors for osteoporosis and secondary causes of osteoporosis. Frost et al. reported calcaneal QUS to be as sensitive as BMD measurements to clinical risk factors for osteoporosis. ${ }^{65}$ Stewart et al. also reported QUS measurements to be sensitive to clinical risk factors for osteoporosis, but reported the strength of the association to be dependent upon the type of QUS device and the variable measured. ${ }^{66}$

Other studies have reported QUS parameters to be decreased in subjects with renal disease, ${ }^{67,68}$ Crohn's disease, ${ }^{69}$ primary hyperparathyroism, ${ }^{70-73}$ Rheumatoid arthritis ${ }^{74}$ and glucocorticoid use. ${ }^{6,75}$ Children and young adults with severe cerebral palsy and taking anticonvulsant therapy (with and without fractures) have been demonstrated to have reduced QUS measurements at the calcaneus. ${ }^{76}$ Damilakis et al. reported a negative correlation of SOS measurements at the radius and tibia with duration of type 1 diabetes in adolescents. ${ }^{77}$ However, other authors have reported limited usefulness of QUS in patients with rheumatoid arthritis and with inflammatory bowel disease. ${ }^{78-80}$ 
Table I

EXamples of studies investigating osteoporotic fractures and Quantitative Ultrasound*

\begin{tabular}{|c|c|c|c|c|c|}
\hline Study & Design & \# site & QUS measurement & QUS measurement site & Age- adjusted relative risk / odds ratio \\
\hline Heaney 1995 & I & Vertebral & VOS & Patella & $2.11(1.14-3.91)$ \\
\hline Bauer 1995 & 2 & Vertebral & BUA & Calcaneus & $1.8(1.4-2.3)$ \\
\hline Gluer 1996 & 2 & Hip & BUA & Calcaneus & $1.9(1.5-2.4)$ \\
\hline Hans 1996 & I & Hip & BUA & Calcaneus & $2.0(1.6-2.4)$ \\
\hline Bauer 1997 & $\mathrm{I}$ & Hip & BUA & Calcaneus & $2.0(1.5-2.7)$ \\
\hline Mele 1997 & $\mathrm{I}$ & Non-spine & Ad-SOS & Phalanx & $1.5(1.1-1.7)$ \\
\hline Pluijm 1999 & 1 & Hip & BUA & Calcaneus & $2.3(1.4-2.7)$ \\
\hline \multirow[t]{2}{*}{ Gnudi 2000} & I & Non-spine & sos & Radius & $3.69(1.18-11.49)$ \\
\hline & & & & Patella & $3.89(1.53-9.90)$ \\
\hline Huopio 2004 & $\mathrm{I}$ & All & SOS & Calcaneus & $1.80(1.27-2.56)$ \\
\hline Bauer 2007 & I & $\begin{array}{l}\text { Hip } \\
\text { Non-spine }\end{array}$ & BUA & Calcaneus & $\begin{array}{l}2.0(1.5-2.8) \\
1.6(1.4-1.8)\end{array}$ \\
\hline
\end{tabular}

* The QUS measurement parameter displayed is that which provided the optimum predictive power in the study outlined

I= prospective, $2=$ cross-sectional

\section{Lifestyle factors}

Physical activity has been demonstrated to have a positive effect on calcaneal QUS parameters. ${ }^{81-86}$ QUS measurements have also been demonstrated to be reduced in smokers compared to non-smokers. ${ }^{87,88}$

\section{T-score equivalence with DXA}

The World Health Organisation (WHO) criteria ${ }^{89}$ cannot be used with QUS to diagnose osteoporosis, ${ }^{90}$ although QUS can be useful as an indication of osteoporosis. A number of authors have reported site and device specific T-score equivalence to DXA. ${ }^{91-99}$ These studies demonstrate that a single diagnostic threshold for QUS is not appropriate and T-score equivalence to DXA is site- and device-specific.

\section{Monitoring therapy}

The poorer precision of QUS in comparison to DXA has resulted in limited applicability for longitudinal use to monitor disease progression or therapeutic intervention. The international QUS consensus group report in 1997 recommends further study of the use of QUS to monitor disease progression or response to therapy, ${ }^{100}$ whilst the National Osteoporosis Society in the UK at present does not recommend the use of QUS for monitoring treatment and states that DXA should be used instead. ${ }^{101}$

Cross-sectional studies of QUS have demonstrated its ability to differentiate between patients treated with HRT compared to age-matched controls. ${ }^{102-104}$ These data are at variance with some of the research into the effect of HRT on calcaneal QUS parameters, which have found limited effects. ${ }^{10,105,106}$ However, Sahotal et al. found a positive effect of HRT at the calcaneus in a longitudinal study over a four year period, although the individual increases for BUA and SOS were not as great as found for lumbar spine and total hip BMD. ${ }^{26}$

A number of longitudinal studies have demonstrated a response of QUS to patients treated with bisphosphonates at the calcaneus and tibia. ${ }^{107-110}$ However, as a result of the poorer precision, the follow-up period is generally required to be longer than that of DXA. ${ }^{109}$

In conclusion, QUS has been extensively researched and has been demonstrated to have the ability to predict fracture, particularly at the hip. However, the predictive ability of QUS appears to be fracture-site, measurementsite and device specific. The correlations between DXA and BMD are weak to moderate, resulting in different subjects being identified as being at risk of fracture by the two different methods. QUS is sensitive to age and menopause-related changes and to clinical risk factors lifestyle factors associated with osteoporosis. Whilst a 
limited ability of QUS to monitor therapeutic intervention has been demonstrated, this is still an area where its poorer precision, in comparison to DXA, results in limited applicability. Whilst DXA remains the gold standard for the diagnosis of osteoporosis, QUS may be of use for the prediction of those at risk of future fracture in areas where there is limited availability of DXA.

\section{References}

I. Langton C M, Palmer S B, Porter R W. The measurement of broadband ultrasonic attenuation in cancellous bone. London: MEP Ltd 1984;13:89-9| 2. Blake G M,Wahner HW, Fogelman I.The evaluation of osteoporosis: dual $x$-ray absorptiometry and ultrasound in clinical practice. London: Martin Dunitz Ltd; 1999.

3. Glüer C-C,Wu CY, Jergas M, Goldstein S A, Genant H K. The quantitative ultrasound parameters reflect bone structure. Calcif Tissue Int 1994;55:46-5.

4. Joly J, Westhovens R, Borghs $H$, Peeters $H$, Tirry J, Nijs J, et al. Reference curve and diagnostic sensitivity for a new ultrasound device for the phalanges, the DBMsonic 1200, in Belgian women. Osteoporos Int 1999;9:284-9.

5. Pluskiewicz W, Drozdzowska B. Ultrasound measurements of proximal phalanges in Polish early postmenopausal women. Osteoporos Int 1998;8:578-83.

6. Orgee JM, Foster H, McCloskey EV, Khan S, Coombes G, Kanis JA.A precise method for the assessment of tibial ultrasound velocity. Osteoporos Int 1996;6: I-7.

7. Tromp AM, Smit JH, Deeg DJ, Lips P. Quantitative ultrasound measurements of the tibia and calcaneus in comparison with DXA measurements at various skeletal sites. Osteoporos Int 1999;9:2308. Lehmann R,Wapniarz M, Kvasnicka HM, Klein K,Allolio B.Velocity of ultrasound at the patella: influence of age, menopause and estrogen replacement therapy. Osteoporos Int 1993;3:308-13.

9. Heaney RP,Avioli LV, Chesnut CH 3rd, Lappe J, Recker RR, Brandenburger $\mathrm{GH}$. Ultrasound velocity, through bone predicts incident vertebral deformity.J Bone Miner Res. 1995; 10:34I-5.

10. Stegman MR, Heaney RP, Recker RR. Comparison of speed of sound ultrasound with single photon absorptiometry for determining fracture odds ratios. J Bone Miner Res 1995; 10:346-52.

I I. Blake G M, Patel R, Fogelman I. Peripheral or axial bone density measurements.J Clin Densitom 1998; I:55-63.

12. Thompson P, Taylor J, Fisher A, Oliver R. Quantitative heel ultrasound in 3180 women between 45 and 75 years of age: compliance, normal ranges and relationship to fracture history. Osteoporos Int 1998;8:2 I I-4. 13. Glüer C C, Vahlensieck M, Faulkner K G, Engelke K, Black D, Genant $H$ K. Site-matched calcaneal measurements of broad-band ultrasound attenuation and single $\mathrm{x}$-ray absorptiometry: do they measure different skeletal properties? J Bone Miner Res 1992 7;9:107I-1079.

14. Mehta S S, Orham K O,Antich P P. Bone elasticity and ultrasound velocity are affected by subtle changes in the organic matrix.J Bone Miner Res 1998; |3:| | |4-12|

15. Njeh C F, Fuerst T, Diessel E, Genant H K. Is quantitative ultrasound dependent on bone structure? A reflection. Osteoporos Int 200 I; I2:I-I5. 16. Wuster C, de Terlizzi F, Becker S, Cadossi M, Cadossi R, Muller R. Usefulness of quantitative ultrasound in evaluating structural and mechanical properties of bone: comparison of ultrasound, dual-energy Xray absorptiometry, micro-computed tomography, and mechanical testing of human phalanges in vitro. Technol Health Care 2005;13:497-5 I0.
17. Portero NR, Arlot ME, Roux JP, Duboeuf F, Chavassieux PM, Meunier PJ. Evaluation and development of automatic two-dimensional measurements of histomorphometric parameters reflecting trabecular bone connectivity: correlations with dual-energy $x$-ray absorptiometry and quantitative ultrasound in human calcaneum. Calcif Tissue Int 2005;77:195-204. 18. Cortet B, Boutry N, Dubois P, Legroux-Gerot I, Cotten A, Marchandise $X$. Does quantitative ultrasound of bone reflect more bone mineral density than bone microarchitecture? Calcif Tissue Int 2004;74:60-7. 19. Turner $\mathrm{C} \mathrm{H}$, Eich $\mathrm{M}$. Ultrasonic velocity as a predictor of strength in bovine cancellous bone. Calcif Tissue Int 1991;49:1 16-119.

20. Waud C E, Lew R and Baran D T.The relationship between ultrasound and densitometric measurements of bone mass at the calcaneus in women. Calcif Tissue Int 1992;51:415-418.

21.Antich P P. Ultrasound study of bone in-vitro. Calcif Tissue Int 1993; 53 : SI57-SI6I.

22. Glüer C-C,Wu CY, Genant H K. Broadband ultrasound attenuation signals depend on trabecular orientation:An in-vitro study. Osteoporos Int 1993;3:185-191.

23.Wu C, Glüer C, Lu Y, Fuerst T, Hans D, Genant H K. Ultrasound characterisation of bone demineralisation. Calcif Tissue Int 1998;62:133-139. 24. Chappard C, Laugier P, Fournier B, Roux C, Berger G. Assessment of the relationship between broadband ultrasound attenuation and bone mineral density at the calcaneus using BUA Imaging and DXA. Osteoporos Int 1997;7:316-322.

25. Laugier P, Droin P, Laval-Jeantet A M, Berger G. In-vitro assessment of the relationship between acoustic properties and bone mass density of the calcaneus by comparison of ultrasound parametric imaging and quantitative computed tomography. Bone 1997;20:157-165.

26. Sahota O, San P, Cawte SA, Pearson D, Hosking D J.A comparison of the longitudinal changes in quantitative ultrasound with dual-energy $x$-ray absorptiometry: The four-ar effects of hormone replacement therapy. Osteoporos Int 2000; 1 1:52-58.

27. Ravaud P, Reny JL, Giraudeau B, Porcher R, Dougados M, Roux $C$. Individual smallest detectable difference in bone mineral density measurements.J Bone Miner Res 1999;14:1449-56.

28. Stewart A, Reid D M. Precision of quantitative ultrasound: comparison of three commercial scanners. Bone 2000;27:139-143.

29. Frost M L, Blake G M, Fogelman I. Contact quantitative ultrasound:An evaluation of precision, fracture discrimination, age-related bone loss and applicability of the WHO Criteria. Osteoporos Int 1999; 10:44 I-449. 30. Frost M L, Blake G M, Fogelman I. Does quantitative ultrasound imaging enhance precision and discrimination? Osteoporos Int 2000; I I:425-433.

31. Barkmann R, Kantorovich E, Singal C, Hans D, Genant H K, Heller M et al. A new method for quantitative ultrasound measurements at multiple skeletal sites. J Clin Densitom 2000;3: I: I-7.

32. Weiss M, Ben-Shlomo A, Hagag P, Rapoport M. Reference database for bone speed of sound measurements by a novel quantitative multi-site ultrasound device. Osteoporos Int 2000; I I:688.

33. Knapp KM, Blake GM, Spector TD, Fogelman I. Multisite quantitative ultrasound: precision, age- and menopause-related changes, fracture discrimination, and T-score equivalence with dual-energy $\mathrm{X}$-ray absorptiometry. Osteoporos Int 2001;12:456-64.

34. Roux C, Fournier B, Laugier P, Chappard C, Kolta S, Dougados M et al. Broadband ultrasound attenuation imaging: a new imaging method in osteoporosis. J Bone Miner Res 1996; I I: I I I2-8.

35. Pettinato AA, Loud KJ, Bristol SK, Feldman HA, Gordon CM. Effects of nutrition, puberty, and gender on bone ultrasound measurements in adolescents and young adults. J Adolesc Health 2006;39:828-34. 36. Vignolo M, Parodi A, Mascagni A, Torrisi C, De Terlizzi F,Aicardi G. Longitudinal assessment of bone quality by quantitative ultrasonography in children and adolescents. Ultrasound Med Biol 2006;32:1003-10. 37. Yang NP, Jen I, Chuang SY, Chen SH, Chou P. Screening for low bone mass with quantitative ultrasonography in a community without 
dual-energy X-ray absorptiometry: population-based survey. BMC Musculoskelet Disord 2006;7:24.

38. Faulkner K G, McClung M R, Coleman L J, Kingston-Sandahl E. Quantitative ultrasound of the heel: correlation with densitometric measurements at different skeletal sites. Osteoporos Int 1994;4:42-47. 39. He Y Q, Fan B, Hans D, Li J,Wu CY, Njeh C F et al. Assessment of a new quantitative ultrasound calcaneus measurement: precision and discrimination of hip fractures in elderly women compared with dual Xray absorptiometry. Osteoporos Int 2000; I I:354-360.

40. Genant HK, Engelke K, Fuerst T, Glüer C-C, Grampp S, Harris ST et al. Noninvasive assessment of bone mineral and structure: state of the art.J Bone Miner Res 1996; 1 I:707-730.

4I. Porter R W, Johnson K, McCutchan J D S. Wrist fracture, heel bone density and thoracic kyphosis:A case control study. Bone 1990; I I:2 I I-2 I4. 42. Grampp S, Genant HK, Mathur A, Lang P, Jergas MI, Takada M et al. Comparisons of noninvasive bone mineral measurements in assessing agerelated loss, fracture discrimination and diagnostic classification.J Bone Miner Res 1997 |2:5:697-7| I.

43. Ross P, Huang C, Davis J, Imose K, Yates J,Vogel J et al. Predicting vertebral deformity using bone densitometry at various skeletal sites and calcaneus ultrasound. Bone 1995;16:325-332.

44. Gnudi S, Ripamonti C, Malavolta N. Quantitative ultrasound and bone densitometry to evaluate the risk of nonspine fractures: a prospective study. Osteoporos Int 2000; I I:518-23.

45. Gluer CC, Cummings SR, Bauer DC, Stone K, Pressman A, Mathur A et al. Osteoporosis: association of recent fractures with quantitative US findings. Radiology 1996; 199:725-32.

46. Porter RW, Miller CG, Grainger D, Palmer SB. Prediction of hip fracture in elderly women: a prospective study. BMJ 1990;30I:638-4I. 47. Bauer DC, Gluer CC, Genant HK, Stone K. Quantitative ultrasound and vertebral fracture in postmenopausal women.J Bone Miner Res 1995; 10:353-8.

48. Hans D, Dargent-Molina P, Schott AM, Sebert JL, Cormier C, Kotzki $\mathrm{PO}$ et al. Ultrasonographic heel measurements to predict hip fracture in elderly women: the EPIDOS prospective study. Lancet. 1996;24:5 I I-4. 49. Bauer DC, Gluer CC, Cauley JA, Vogt TM, Ensrud KE, Genant HK et al. Broadband ultrasound attenuation predicts fractures strongly and independently of densitometry in older women.A prospective study.Arch Intern Med. 1997; 157:629-34.

50. Mele R, Masci G,Ventura V, de Aloysio D, Bicocchi M, Cadossi R. Threeyear longitudinal study with quantitative ultrasound at the hand phalanx in a female population. Osteoporos Int 1997;7:550-7.

5I. Pluijm SM, Graafmans WC, Bouter LM, Lips P. Ultrasound measurements for the prediction of osteoporotic fractures in elderly people. Osteoporos Int 1999;9:550-6.

52. Huopio J, Kroger H, Honkanen R, Jurvelin J, Saarikoski S,Alhava E. Calcaneal ultrasound predicts early postmenopausal fractures as well as axial BMD.A prospective study of 422 women. Osteoporos Int 2004;15:190-5

53. Bauer DC, Ewing SK, Cauley JA, Ensrud KE, Cummings SR, Orwoll ES. Quantitative ultrasound predicts hip and non-spine fracture in men: the MrOS study. Osteoporos Int 2007; |8:77|-7.

54. Marin F, Gonzalez-Macias J, Diez-Perez A, Palma S, Delgado-Rodriguez M. Relationship between bone quantitative ultrasound and fractures: a meta-analysis. Bone Miner Res 2006;21:I I 26-35.

55. Meszaros S, Toth E, Ferencz V, Csupor E, Hosszu E, Horvath C. Calcaneous quantitative ultrasound measurements predicts vertebral fractures in idiopathic male osteoporosis.Joint Bone Spine 2007;74:79-84. 56. Frediani B,Acciai C, Falsetti P, Baldi F, Filippou G, Siagkri C et al. Calcaneus ultrasonometry and dual-energy $\mathrm{X}$-ray absorptiometry for the evaluation of vertebral fracture risk. Calcif Tissue Int 2006;79:223-9. 57. Gluer MG, Minne HW, Gluer CC, Lazarescu AD, Pfeifer M, Perschel $\mathrm{FH}$ et al. Prospective identification of postmenopausal osteoporotic women at high vertebral fracture risk by radiography, bone densitometry, quantitative ultrasound, and laboratory findings: results from the PIOS study.J Clin Densitom 2005;8:386-95.

58. Maggi S, Noale M, Giannini S,Adami S, Defeo D, Isaia G et al. Quantitative heel ultrasound in a population-based study in Italy and its relationship with fracture history: the ESOPO study. Osteoporos Int 2006; 17:237-44.

59. Clowes JA, Eastell R, Peel NF.The discriminative ability of peripheral and axial bone measurements to identify proximal femoral, vertebral, distal forearm and proximal humeral fractures: a case control study. Osteoporos Int 2005;16:1794-802.

60. Kanis JA, Johnell O, Oden A, De Laet C, de Terlizzi F. Ten-year probabilities of clinical vertebral fractures according to phalangeal quantitative ultrasonography.Osteoporos Int 2005; 16:1065-70. 6I. Gnudi S, Ripamonti C. Quantitative ultrasound at the phalanxes discriminates osteoporotic women with vertebral but not with hip fracture.Ultrasound Med Biol 2004;30:357-61.

62. Drozdzowska B, Pluskiewicz W, de Terlizzi F.The usefulness of quantitative ultrasound at the hand phalanges in the detection of the different types of nontraumatic fractures. Ultrasound Med Biol 2003;29:1545-50.

63. Guglielmi G, Njeh CF, de Terlizzi F, De Serio DA, Scillitani A, Cammisa $M$ et al. Palangeal quantitative ultrasound, phalangeal morphometric variables, and vertebral fracture discrimination. Calcif Tissue Int 2003;72:469-77.

64. Hartl F, Tyndall A, Kraenzlin M, Bachmeier C, Guckel C, Senn U et al. Discriminatory ability of quantitative ultrasound parameters and bone mineral density in a population-based sample of postmenopausal women with vertebral fractures: results of the Basel Osteoporosis Study.J Bone Miner Res 2002;17:321-30

65. Frost M L, Blake G M, Fogelman I. Quantitative ultrasound and bone mineral density are equally strongly associated with risk factors for osteoporosis. J Bone Miner Res 2001;2:406-416.

66. Stewart A, Felsenberg D, Eastell R, Roux C, Gluer CC, Reid DM.

Relationship between risk factors and QUS in a European Population:The OPUS study. Bone. 2006;39:609-15.

67. Wittich A,Vega E, Casco C, Marini A, Forlano C, Segovia F et al. Ultrasound velocity of the tibia in patients on haemodialysis. J Clin Densitometry 1998;2:157-163.

68. Pluskiewicz W, Przedlacki J, Drozdzowska B,Wlodarczyk D, Matuszkiewicz-Rowinska J,Adamczyk P. Quantitative ultrasound in monitoring of skeletal status in adults with end-stage renal disease. Ultrasound Med Biol 2006;32:152I-7.

69. Robinson R J, Carr I, Iqbal S J, al-Azzawi F,Abrams K, Mayberry J F. Screening for osteoporosis in crohn's disease.A detailed evaluation of calcaneal ultrasound. Eur J Gastroenterol Hepatol I998;2: I37-40 70. Gomez A C, Schott A M, Hans D, Niepomniszcze H, Mautalen C A, Meunier P J. Hyperparathyroidism Influences ultrasound bone measurements on the os calcis. Osteoporos Int 1998;8:455-459. 7I. Ingle B M,Thomas W E G, Eastell R. Differential effects on ultrasound properties of bone in primary hyperparathyroidism. Osteoporos Int 1998;8:S3:S56.

72. Ingle BM, Thomas WE, Eastell R. Differential effects of primary hyperparathyroidism on ultrasound properties of bone. Osteoporos Int 2002; 13:572-8.

73. Chappard C, Roux C, Laugier P, Paillard M, Houillier P. Bone status in primary hyperparathyroidism assessed by regional bone mineral density from the whole body scan and QUS imaging at calcaneus. Joint Bone Spine 2006;73:86-94.

74. Cryer JR, Otter SJ, Bowen CJ. Use of quantitative ultrasound scans of the calcaneus to diagnose osteoporosis in patients with rheumatoid arthritis. J Am Podiatr Med Assoc 2007;97:108-14. 
75. Blanckaert F, Cortet B, Coquerelle B, Flipo R M, Duquesnoy B, Matchandise $\mathrm{X}$ et al. Contribution of calcaneal ultrasonic assessment to the evaluation of postmenopausal and glucocorticoid-induced osteoporosis. Rev Rhum 1997 64:305-313.

76. Jekovec-Vrhovsek M, Kocijancic A, Prezelj J. Quantitative ultrasound of the calcaneus in children and young adults with severe cerebral palsy. Dev Med Child Neurol 2005;47:696-8.

77. Damilakis J, Galanakis E, Mamoulakis D, Sbyrakis S, Gourtsoyiannis N. Quantitative ultrasound measurements in children and adolescents with: type I diabetes. Calcif Tissue Int 2004;74:424-8.

78. Pfeil A, Bottcher J, Mentzel HJ, Lehmann G, Schafer ML, Kramer A et al. Multi-site quantitative ultrasound compared to dual energy $\mathrm{X}$-ray absorptiometry in rheumatoid arthritis: effects of body mass index and inflamed soft tissue on reproducibility. Rheumatol Int 2006;26: I084-90. 79. Bottcher J, Pfeil A, Mentzel H, Kramer A, Schafer ML, Lehmann G et al. Peripheral bone status in rheumatoid arthritis evaluated by digital $\mathrm{X}$-ray radiogrammetry and compared with multisite quantitative ultrasound. Calcif Tissue Int 2006;78:25-34.

80. Schwartz DA, Connolley CD, Koyama T,Wise PE, Herline AJ. Calcaneal ultrasound bone densitometry is not a useful tool to screen patients with inflammatory bowel disease at high risk for metabolic bone disease. Inflamm Bowel Dis 2005; I 1:749-54.

81.Adami S, Giannini S, Giorgino R, Isaia G, Maggi S, Sinigaglia L et al. The effect of age, weight, and lifestyle factors on calcaneal quantitative ultrasound: the ESOPO study. Osteoporos Int 2003; I4:198-207. 82. Adami S, Giannini S, Giorgino R, Isaia GC, Maggi S, Sinigaglia L et al. Effect of age, weight and lifestyle factors on calcaneal quantitative ultrasound in premenopausal women: the ESOPO study. Calcif Tissue Int 2004;74:317-2I.

83. Babaroutsi E, Magkos F, Manios Y, Sidossis LS. Body mass index, calcium intake, and physical activity affect calcaneal ultrasound in healthy Greek males in an age-dependent and parameter-specific manner.J Bone Miner Metab 2005;23:157-66.

84. Yung PS, Lai YM, Tung PY,Tsui HT, Wong CK, Hung VW et al. Effects of weight bearing and non-weight bearing exercises on bone properties using calcaneal quantitative ultrasound. Br J Sports Med 2005;39:547-5 I. 85. Oral A, Tarakci D, Disci R. Calcaneal quantitative ultrasound measurements in young male and female professional dancers. J Strength Cond Res 2006;20:572-8.

86. Blanchet C, Giguere Y, Prud'homme D, Turcot-Lemay L, Dumont M, Leduc $\mathrm{G}$ et al. Leisure physical activity is associated with quantitative ultrasound measurements independently of bone mineral density in postmenopausal women. Calcif Tissue Int 2003;73:339-49.

87. Barr R J, Stewart A, McDonagh B, Torgerson D J, Reid D. Effect of smoking and alcohol on quantitative ultrasound parameters in the elderly. J Bone Miner Res 200I;16:S277.

88. Bernaards CM, Twisk JW, Snel J, van Mechelen W, Lips P, Kemper HC. Smoking and quantitative ultrasound parameters in the calcaneus in 36year-old men and women. Osteoporos Int 2004;15:735-4I.

89.Anonymous. WHO Study Group.Assessment of Fracture Risk and its Application to Screening for Postmenopausal Osteoporosis. Geneva 1994. 90. Leib ES, Lewiecki EM, Binkley N, Hamdy C. Official positions of the International Society for Clinical Densitometry.J Clin Densitom 2004;7: I-6. 91. Gudmundsdottir SL, Indridason OS, Franzson L, Sigurdsson G. Age-related decline in bone mass measured by dual-energy $\mathrm{X}$-ray absorptiometry and quantitative ultrasound in a population-based sample of both sexes: identification of useful ultrasound thresholds for osteoporosis screening.J Clin Densitom 2005;8:80-6.

92. Zochling J, Nguyen TV, March LM, Sambrook PN. Quantitative ultrasound measurements of bone: measurement error, discordance, and their effects on longitudinal studies. Osteoporos Int 2004;15:619-24
93. Rothenberg RJ, Boyd JL, Holcomb JP. Quantitative ultrasound of the calcaneus as a screening tool to detect osteoporosis: different reference ranges for caucasian women, african american women, and caucasian men. J Clin Densitom 2004;7:101-10.

94. Knapp KM, Blake GM, Spector TD, Fogelman I. Can the WHO definition of osteoporosis be applied to multi-site axial transmission quantitative Ultrasound? Osteoporos Int 2004;15:367-74.

95. Lopez-Rodriguez F, Mezquita-Raya P, de Dios Luna J, Escobar-Jimenez F, Munoz-Torres M. Performance of quantitative ultrasound in the discrimination of prevalent osteoporotic fractures in a bone metabolic unit. Bone 2003;32:57I-8.

96. Hans D, Hartl F, Krieg MA. Device-specific weighted T-score for two quantitative ultrasounds: operational propositions for the management of osteoporosis for 65 years and older women in Switzerland. Osteoporos Int 2003; 14:25I-8.

97. Damilakis J, Perisinakis K, Gourtsoyiannis N. Imaging ultrasonometry of the calcaneus: optimum T-score thresholds for the identification of osteoporotic subjects. Calcif Tissue Int 2001;68:219-24.

98. Jorgensen HL, Warming L, Bjarnason NH,Andersen PB, Hassager C. How does quantitative ultrasound compare to dual $\mathrm{X}$-ray absorptiometry at various skeletal sites in relation to the WHO diagnosis categories? Clin Physiol 200I;2I:5I-9.

99. Frost ML, Blake GM, Fogelman I. Can the WHO criteria for diagnosing osteoporosis be applied to calcaneal quantitative ultrasound? Osteoporos Int 2000; II:32I-30.

100. Glüer C-C. Quantitative Ultrasound Techniques for the Assessment of Osteoporosis: Expert Agreement on Current Status. J Bone Miner Res 1997;8:1280-1288.

I0I. Anonymous. National Osteoporosis Society. The Use of Quantitative Ultrasound in the Management of Osteoporosis in Primary or Secondary Care. NOS (UK) 1998.

102. Knapp KM, Blake GM, Spector TD, Fogelman I. Differential effects of hormone replacement therapy on bone mineral density and axial transmission ultrasound measurements in cortical bone. Osteoporos Int 2003;14:289-94.

103.Weiss M, Ben Shlomo A, Hagag P, Rapoport M, Ish-Shalom S. Effect of estrogen replacement therapy on speed of sound at multiple skeletal sites. Maturitas 2000;35:237-43.

104. Lehmann R, Wapniarz M, Kvasnicka H M, Klein K,Allolio B.Velocity of ultrasound at the patella: influence of age, menopause and estrogen replacement therapy. Osteoporos Int 1993;3:308-313.

105. Rosenthall L, Caminis J,Tenehouse. Calcaneal ultrasonometry: response to treatment in comparison with dual $\mathrm{x}$-ray absorptiometry measurements of the lumbar spine and femur. Calcif Tissue Int 1999;64:200-204

106. Balikian P, Burbank K, Houde, J, Crane G, Nairus J,Ahmadi S et al. Bone mineral density and broadband ultrasound attenuation with estrogen treatment of postmenopausal women.J Clin Densitometry 1998;1:19-26.

107. Gonnelli S, Cepollaro C, Montagnani A, Bruni D, Caffarelli C, Breschi $M$ et al. Alendronate treatment in men with primary osteoporosis: a three-year longitudinal study. Calcif Tissue Int 2003;73:133-9.

108. Gonnelli S, Cepollaro C, Montagnani A, Martini S, Gennari L, Mangeri $M$ et al. Heel ultrasonography in monitoring alendronate therapy: a fouryear longitudinal study. Osteoporos Int 2002;|3:415-2I.

109. Frost ML, Blake GM, Fogelman. Changes in QUS and BMD measurements with antiresorptive therapy: a two-year longitudinal study. Calcif Tissue Int 200I;69:138-46.

I I0. Weiss M, Koren-Michowitz M, Segal E, Ish-Shalom S. Monitoring response to osteoporosis therapy with alendronate by a multisite ultrasound device: a prospective study.J Clin Densitom 2003;6:219-24. 